\title{
Chapter 1 \\ In the Age of Cities: The Impact of Urbanisation on House Prices and Affordability
}

\author{
Lisette van Doorn, Amanprit Arnold, and Elizabeth Rapoport
}

\section{Introduction}

Global megatrends are re-shaping the world economic order. From urbanisation, to the rise of the global middle classes, ageing population and technological trends, these changes all pose major implications for the built environment and demand for housing in the short- and long-term. According to the latest projections by the United Nations, the world's population is expected to grow by 2.9 billion in the next 33 years and potentially another three billion by the end of the century. At the same time, the move towards cities is expected to continue, driven by economic, climate change and conflict motivations, as a result of which, 80-90\% of people are expected to live in cities by 2100 (United Nations 2017).

As population growth and urbanisation continue, cities are faced with a number of challenges such as air pollution, congestion, social issues and pressure on housing markets. The pressure on housing markets can be analysed from different perspectives. Looking at the issue from a financial market perspective, the issue of financial market stability is a key element. However, when addressing the issue from a social and economic perspective, the focus lies more on risks like affordability, city competitiveness and social segregation.

This paper examines the role of urbanisation and current megatrends we are seeing in today's world, as well as the implications of the growing popularity of residential property as a real estate investment class, on the housing market in major cities. Unintended consequences of rising house prices, housing shortages and unaffordability are explored followed by potential solutions. In order for cities to be successful, careful consideration needs to be given to managing and resolving housing affordability challenges. This is a step towards creating a balanced housing

L. van Doorn $(\varangle) \cdot$ A. Arnold $\cdot$ E. Rapoport

Urban Land Institute, London, UK

e-mail: lisette.vandoorn@uli.org; amanprit.arnold@uli.org; elizabeth.rapoport@uli.org 
market, as seen from both a financial market as well as economic and social perspective.

\section{The Popularity of Major Cities}

At the start of the industrial age, large urban centres in the United States and Europe were often crowded and crumbling. The emergence of car ownership started to mobilise urban populations as travel beyond the cities and towns got easier. This also helped the middle-class to improve the quality of lives with access to fresh air, green space and spacious affordable homes. Not only citizens left the cities, also companies moved to suburban office parks and retail concentrated in car-accessible out of town shopping centres. Continued sprawl in the 1980s further increased residents' reliance on cars along with pollution, congestion and pollution. People living farther from urban centres spent more time commuting. Objections to urban sprawl arose slowly and urban planners began rethinking policies and developers started to encourage regeneration and mixed-use developments in city centres, in line with a growing focus on sustainability and carbon emission reduction.

The transition, in many advanced economies, from an industrial to a service-led economy, has had profound implications for cities. Many formerly industrial cities have transformed themselves. Older industrial zones have become the focus of strategies to foster the development of the service, tourism, knowledge and creative economies. Polluted waterfronts have been regenerated, market squares have become public spaces again and railway station districts are renovated. This has been supported by a wave of investment in infrastructure, and cultural and recreational amenities.

Consequently, cities are increasingly popular as locations to live, work, play and invest. Cities have become magnets for economic, cultural and social activities. They now attract not only a new generation of city dwellers, and a previously suburban generation that rediscovered the appeal of city living and urban lifestyle, but also businesses and institutional investors that are focusing exclusively on urban areas. Impacted by the rise of the sharing economy, and a demand for greater flexibility, in many cities the proportion of residents who prefer to rent rather than buy their homes is rising.

At the same time, urban demographics are rapidly changing. In 2015, the International Organization of Migration (IOM) recorded in excess of one million arrivals in Europe, with migrants arriving from more than 100 countries (McKinsey Global Institute 2016). Many of these people settle in cities. In Europe, 25\% of the population is already aged 60 years or over and that proportion is projected to reach $35 \%$ in 2050 and $36 \%$ in 2100 (United Nations 2017). As a result of this, we now have many different generations living in cities. While previously, families tended to move out when children came, more and more are staying in the city, with older people also remaining in, or returning to cities when they retire. 


\section{Consequences of the Rise of Major Cities: Housing Affordability and Its Challenges}

One of the consequences of the growing popularity of cities, particularly in large, global cities, has been a strong increase in demand for housing. As shown in Fig. 1.1, during the financial crisis of the late 2000s, in many cities, especially in the Netherlands, the housing market came to a complete standstill. The resulting mismatch between supply and demand intensified due to inflows of people in cities and rapidly changing demands. When construction resumed, it could not pick up quickly enough to satisfy the demand for housing. As a result, house prices and the overall cost of living in many cities have increased quickly. This has not only led to financial market risks, but also to a housing affordability crisis that drives both lower skilled workers and talented young professionals out of major cities.

Recent research by MSCI found that out of 97 countries analysed, only four had affordable rental real estate available that covered at least $50 \%$ of their urban populations, and only six countries had affordable mortgage conditions for middle-income populations. This 'unaffordability bubble' for median income residents, estimated to be more than 50 million households by 2020 , could potentially be left out of affordable options within some of the biggest cities in the world (LopezAlcala 2016). In many cities, high rents and house prices mean that young people are not able to save enough to put down the deposit required to qualify for a mortgage and purchase a property, leading to the rise of "generation rent".

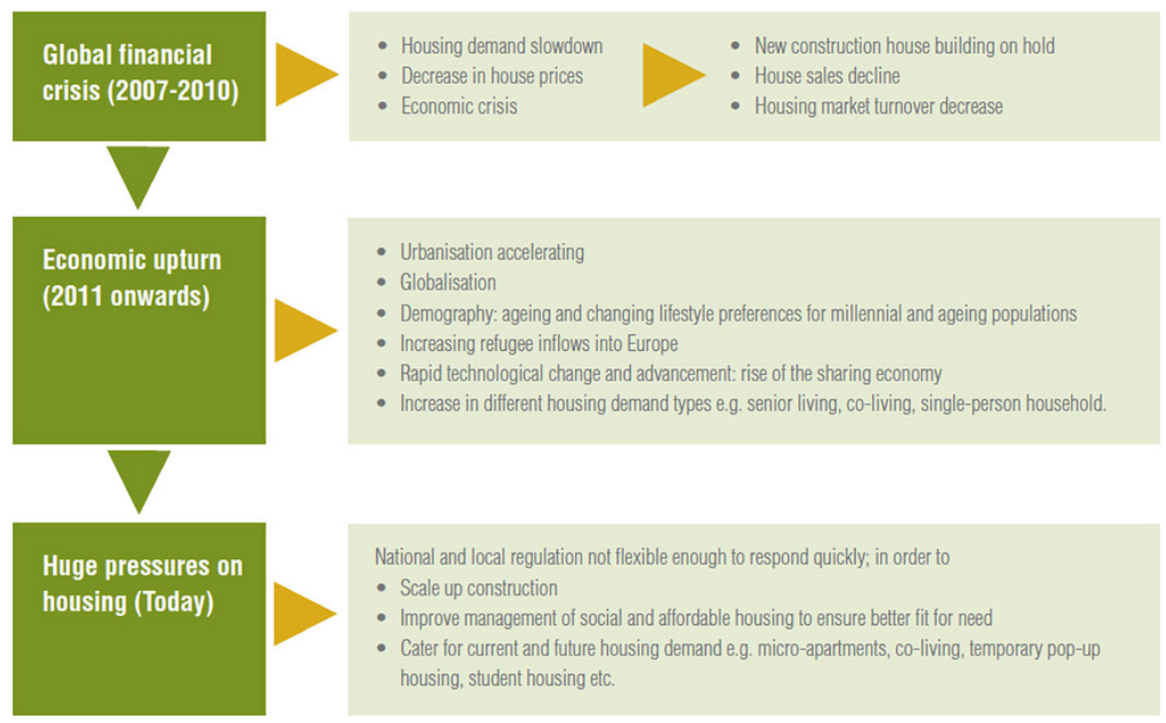

Fig. 1.1 Timescale of contributing factors to the current housing market picture (ULI 2018) 


\section{ULI Housing Affordability Research-Preliminary Findings}

Despite media and political attention on ever-rising housing costs, ULI members have also observed that institutional investors lacked a consistent global measure of housing affordability. The ULI European Residential Council, in partnership with Savills, looked at housing affordability across five European cities: Amsterdam, Barcelona, Berlin, London and Warsaw. The research analyses the experience of different types of households with lower, median and upper quartile disposable incomes, and the percentage of income spent on housing, whether rent or mortgage. Initial findings are that affordability issues vary depending on household and tenure type. Using a single average income to rent/mortgage ratio for a city, as is commonly done, does not reflect the true costs, and challenges, faced by different types of households. The short-term costs of renting are lower than owning, but the lifetime costs of owning outweighs this. People are paying $20 \%$ less on mortgage payments than in rent in most cities. The working paper with findings will be available in 2019 (ULI 2018).

\subsection{Causes of the Housing Affordability Crisis}

Figure 1.2 below sets out some of the causes of the affordability crisis in major cities, which are discussed in more detail below.

\section{Increased Investment in Real Estate and Residential in Particular}

Global capital and foreign real estate investment into cities is more and more focused on investing in residential, which puts pressure on house prices. However, investors can also play a role in maintaining a more stable housing market through the different cycles. More information about the impact of institutional investors on the housing market can be found in Sect. 4.

\section{Limited Land Supply and Complexity of Delivery}

In many cities, land supply for new developments is very limited. In order to develop in the urban core and prevent further urban sprawl, in many European cities new housing is created through large, complex urban regeneration projects. These projects involve a wide range of actors, large sums of capital and a combination of infrastructure and real estate development. As a result, they usually take a long time from initiation to completion.

\section{Rising Costs}

Due to the lack of available land in combination with the strong demand, land values have increased rapidly which is an obstacle to affordable housing. On top of expensive land costs in cities, construction costs are largely determined by market forces including a shrinking labour force, rising material and resource costs and the market expectation of low-density housing. These all influence house prices and what people can afford to rent and buy. 


\begin{tabular}{|c|c|c|c|c|}
\hline Cause & Global & Europe & National & City \\
\hline Global capital flows and investment into local cities & $x$ & $x$ & & \\
\hline Mobility and migration to cities & $\mathbf{x}$ & $\mathbf{x}$ & $\mathbf{x}$ & \\
\hline $\begin{array}{l}\text { Megatrends } \\
\text { i.e. demographics and disruptive technology }\end{array}$ & $\mathbf{x}$ & $x$ & & $\mathbf{x}$ \\
\hline $\begin{array}{l}\text { Social preferences and change } \\
\text { i.e urban vs. suburban lifestyle }\end{array}$ & $\mathbf{x}$ & & $\mathbf{x}$ & $\mathbf{x}$ \\
\hline Limited land supply & & & $\mathbf{x}$ & $\mathbf{x}$ \\
\hline Housing shortage and demand & & & $\mathrm{x}$ & $x$ \\
\hline $\begin{array}{l}\text { Commodity prices } \\
\text { i.e. Construction material and labour costs }\end{array}$ & $\mathbf{x}$ & & $\mathbf{x}$ & \\
\hline \multicolumn{5}{|l|}{ Regulation } \\
\hline - Planning and land use & & & $\mathrm{x}$ & $x$ \\
\hline - Building & & $x$ & $x$ & \\
\hline - Environmental & & $x$ & $x$ & \\
\hline - Tax and subsidies & & & $\mathrm{x}$ & \\
\hline - Monetary and mortgage & & & $\mathrm{x}$ & $x$ \\
\hline - Private rental market & & & & $\mathrm{x}$ \\
\hline
\end{tabular}

Fig. 1.2 Multi-layered geographic causes of housing affordability (ULI 2018). Note: x symbolises the geographical level that creates the cause for housing unaffordability

\section{Inflexible Regulation}

Accommodate to changing demands created by demographic shifts requires new types of housing. These include flexible micro-living spaces, affordable housing with more space for families, and housing tailored to the needs of elderly people. In many cities, regulations do not permit new and innovate housing typologies, or slow down the process of developing these. Overall, Urban Land Institute (ULI) members have found that in the European cities where they operate, regulation appears to react slowly to the changing demands of the housing market. This then leads to low rates of new construction, slow delivery of new housing stock, and higher prices for new units. The overall impact of all these factors is low elasticity of housing supply, and high housing costs. If applied in the right way, regulation can help to control the housing market such as capping rents to make housing affordable and appropriate for everyone.

\section{ULI Affordable Housing Game initiative}

In 2017, ULI in partnership with a city gaming company, Play the City, brought ULI members and partners together to develop innovative, and collaborative approaches to increase a city's supply of affordable housing. Members played the game three times, twice in Dublin and once in Amsterdam. A common theme in all three games was that affordable housing is not just about 
housing but a wider range of issues, including high-quality placemaking, cultural, educational and transport infrastructure, and collective work places. It also found that current regulation is not suitable for solving housing affordability issues among these cities. Players often spoke about the need for public space and amenities to create good density for mixed-income residents. Infrastructure improvement would make other affordable housing areas within a city more desirable. In areas such as the city centre where land is scarce, players recommended strategies to manage the existing stock in a way that will create a greater diversity of housing options, so that it is easier for residents to move when their needs change (ULI and Play the City 2018).

\section{The Impact of Institutional Investment on the Housing Market}

Global investors increasingly recognise the benefits of investing in real estate as a means to diversify their portfolios and focus on income return. Recent INREV research (see Fig. 1.3) shows that globally, real estate makes up $8.9 \%$ of institutional investors' total assets. Approximately half of the institutional investors expect their allocations to real estate to increase over the next 2 years (INREV 2018). This may have a significant impact on the real estate market. With more capital seeking real estate to invest in, prices might be pressured even further. However, on the other hand, the presence of long-term institutional investors in the market can help to make real estate cycles less volatile, as these types of investors tend not to overbid for properties at the peak of the market, and do not have to sell in a downturn (INREV 2013).

Until about 5-10 years ago, investors made investment decisions based on the overall attractiveness of a country or region. Today, many are increasingly focusing on well performing cities. Cities are evaluated through a combination of top down and bottom up analysis. Cities' performance in renowned international city indices are key inputs for these kinds of analyses. While in the past, the governance

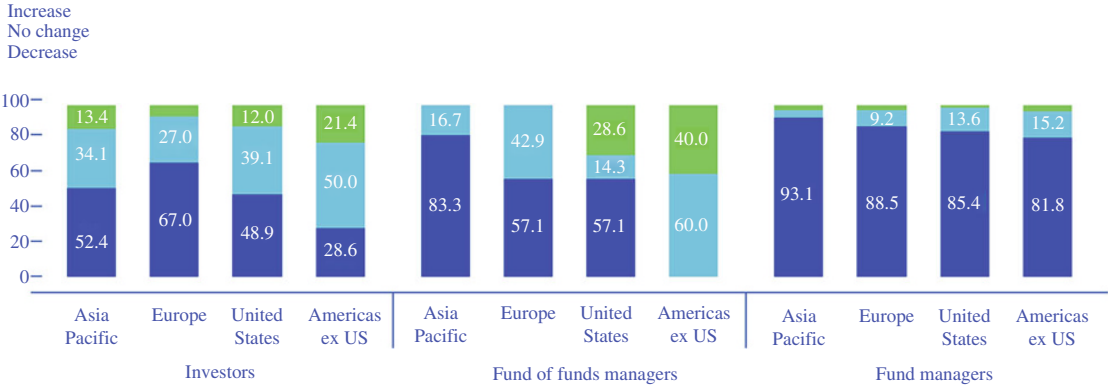

Fig. 1.3 Expected changes to real estate allocations by region over the next 2 years (INREV 2018) 
framework, competitive climate and economic performance were key indicators, today investors tend to focus more and more on 'softer' factors such as connectivity, quality of life, the capability to attract talent and innovative businesses.

This focus is clearly visible in the preferences of institutional investors regarding the type of cities where they see the best development and investment opportunities. Cities in the top 10, as shown in Fig. 1.4, reflect cities which score high on elements such as connectivity, sustainability and quality of living.

In some countries such as the Netherlands, France and Germany, residential housing has been a key real estate investment sector for investors for many years. However, in many other countries in Europe, until about 5-10 years ago, institutional investors concentrated almost exclusively on commercial real estate, such as offices and retail. The lack of scale and the burden of intensive property management were often cited as reasons not to invest in residential real estate.

However, following the financial crisis, many investors looked to diversify their portfolios. They recognised the huge opportunity given the demand and supply characteristics of residential property in cities and began expanding into residential real estate, which is known for having a non-cyclical character, continuing to perform even in a downturn, as people always need somewhere to live (see

Fig. 1.4 Cities ranking 2018 (PwC and ULI 2017)

\begin{tabular}{|c|l|}
\hline $\begin{array}{c}\text { Overall } \\
\text { ranking }\end{array}$ & Cities \\
\hline 1 & Berlin \\
\hline$=2$ & Copenhagen \\
\hline$=2$ & Frankfurt \\
\hline 4 & Munich \\
\hline 5 & Madrid \\
\hline 6 & Hamburg \\
\hline 7 & Dublin \\
\hline 8 & Stockholm \\
\hline 9 & Luxembourg \\
\hline 10 & Amsterdam \\
\hline
\end{tabular}



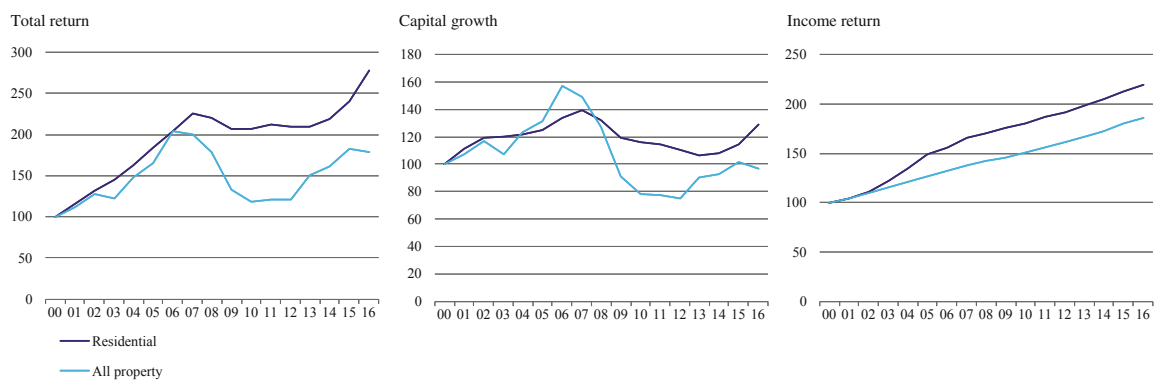

Fig. 1.5 Indexed long term return perspective $(2000=100)$ for residential versus all property (Europe) (INREV 2018)

Fig. 1.5). Today there is a growing amount of institutional capital, both international and domestic, flowing into the residential sector. Over time the percentage of international capital being investing in residential has grown in particular. This shift was also influenced by changing demographics and the emergence of new products, such as student housing.

This shift can be seen in the change in the way respondents to the annual ULI/PwC Emerging Trends in Real Estate ${ }^{\circledR}$ Europe report have ranked the investment prospects of residential real estate (Fig. 1.6). While in 2009, only one of the sectors ranked in the top ten for investment prospects was residential, in the 2018 report, five of the sectors ranked in the top 10 were related to residential, including private sector residential, student housing, retirement living, housebuilding for sale and serviced apartments (PwC and ULI 2017).

Products such as retirement living, student accommodation, build-to-rent and high-quality housing close to workplaces can all offer long-term, stable returns, which are attractive to investors, including pension funds who are looking to increase the real estate component of their portfolios. This increase in investment adds to the overall housing supply and variety of options available provided in a transparent and professional way.

\section{Potential Solutions}

There is no single solution to the rising house prices and housing affordability challenge in cities; what is required is a multi-faceted approach including actions by the public, private and not-for-profit sectors. And while the housing prices and affordability issue can be analysed from many different perspectives, the fundamental factors for solving the issue require a significant increase in the supply of housing and ensuring a better fit between the house and the resident.

There are a number of key elements which should be taken into consideration when aiming to speed up construction and delivery of housing. 

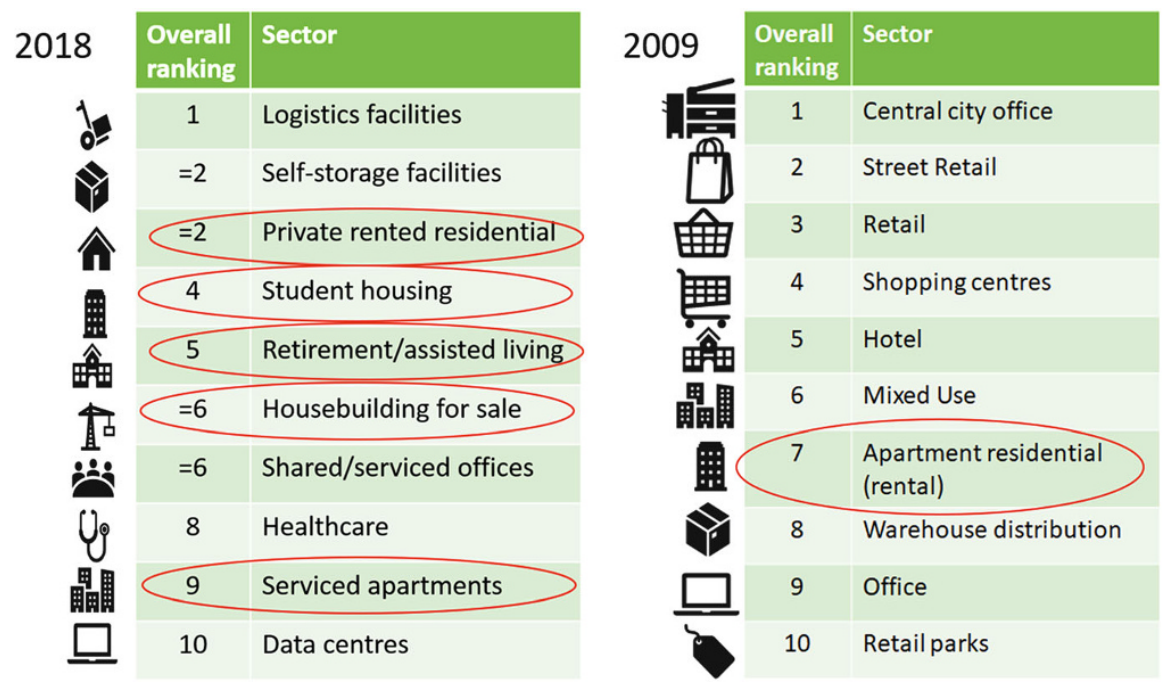

Fig. 1.6 Sector prospects in 2018 and 2009 (PwC and ULI 2008, 2017)

Good density: Previous ULI research, and conversations with members have identified some of the most important changes required to enable an increase in housing supply that aligns with the principles of good density; mixed-use, wellconnected environments with high-quality green and public space (Clark and Moir 2015). By densifying cities in the right way, ensuring mixed use, green space and good connectivity, we create the business case and critical mass to provide sufficient public transport and amenities for people to enjoy them in their neighbourhood. This creates vibrant, liveable and sustainable communities, while also reducing energy consumption and emissions and decreasing the infrastructure costs per resident.

Streamline regulation: National polices do not always address housing affordability challenges in cities as individual cities have their own set of specific circumstances and market structure that are unique to the city, that it requires standalone city-level policies and regulation whether it would be planning or the rental market. However, there has been a recent focus on the role of the planning system to boost housing supply through a faster planning process and flexible planning and building regulations. We are also seeing a slow change in regulation where minimum unit sizes are required to make housing liveable.

Public private collaboration: Delivering adequate housing in major cities is a complex process and requires close collaboration between the public and private sectors. Productive collaborations are essential to attract investment, particularly from international and institutional investors that are increasingly interested in the residential sector and for projects that have clear risk sharing components. Working together, the public and private sectors can combine their respective areas of expertise to ensure that projects deliver the housing, and supporting infrastructure, that citizens require. In particular, as ULI has learned through playing our affordable 
housing game in Dublin and Amsterdam, the public and private sectors will need to work together and involve citizens to develop creative solutions to creating an adequate supply of social and affordable housing.

Speed up construction: Modern methods of housing construction and off-site manufacturing can be viewed as a solution to help speed up the delivery of homes and at an affordable level. With technological change, new innovative housing approaches are happening and there are some early signs of manufacturing-led foreign companies overcoming traditional barriers to market entry through use of pre-manufactured construction products as opposed to traditional construction methods (Farmer 2016).

\section{Conclusions}

Cities can be viewed as both the source of and solution to many of today's economic, social and environmental challenges and they are evolving as places for people to live, work and play and for investors to invest in. However, many cities across the world increasingly experience housing as being one of the most critical urban challenges in cities today. Despite the rise of cities, along with it comes a number of unintended consequences including rising house prices, affordable housing shortages and inflexible housing stock. These problems in turn threaten not just financial market stability, but also quality of life and integration, as well as city competitiveness on the national and international scale.

In response, ULI recommends that cities should focus on creating more housing, including a more diverse range of options so that the housing stock can better meet the needs of different household types and income levels. By applying the principles of "good density"-mixed, use, well-connected environments with high-quality placemaking, integrated urban environments can be created that cater to a range of income and population groups and contribute to the vibrancy and authenticity of a city.

Cities require continuous management and flexible planning policies and regulations is one way forward. There is also a new wave of investment in affordable housing as it offers long-term returns and a broader societal impact. Solving housing affordability challenges is part of a bigger task in creating great cities that remain competitive and where people can afford to enjoy urban lifestyles. 
1 In the Age of Cities: The Impact of Urbanisation on House Prices and. .

\section{References}

Clark, G., \& Moir, E. (2015). Density: Drivers, dividends and debates. London: Urban Land Institute.

Farmer, M. (2016). The farmer review of the UK construction labour model. Accessed April 23, 2018, from http://www.constructionleadershipcouncil.co.uk/wp-content/uploads/2016/10/ Farmer-Review.pdf

INREV. (2013). Real estate as a long-term investment: The impact of regulatory change on longterm investing strategies and on the real economy. Amsterdam: INREV.

INREV. (2018). Investment intentions survey. Amsterdam: INREV.

Lopez-Alcala, M. (2016). The crisis of affordability in real estate. London: MSCI.

McKinsey Global Institute. (2016). People on the move: Global migrations' impact and opportunity. Accessed April 23, 2018, from http://www.mckinsey.com/global-themes/employmentand-growth/global-migrations-impact-and-opportunity?cid=other-eml-alt-mgi-mgi-oth-1612

PwC and ULI. (2008). Emerging trends in real estate Europe 2009. London: PwC.

PwC and ULI. (2017). Emerging trends in real estate Europe 2018. London: PwC.

ULI. (2018). European housing affordability. London: Urban Land Institute.

ULI and Play the City. (2018). Amsterdam affordable housing game report. London: Urban Land Institute.

United Nations. (2017). World population prospects: The 2017 revision, key findings \& advance tables (Working Paper No. ESA/P/WP/248). New York: United Nations.

Open Access This chapter is licensed under the terms of the Creative Commons Attribution 4.0 International License (http://creativecommons.org/licenses/by/4.0/), which permits use, sharing, adaptation, distribution and reproduction in any medium or format, as long as you give appropriate credit to the original author(s) and the source, provide a link to the Creative Commons licence and indicate if changes were made.

The images or other third party material in this chapter are included in the chapter's Creative Commons licence, unless indicated otherwise in a credit line to the material. If material is not included in the chapter's Creative Commons licence and your intended use is not permitted by statutory regulation or exceeds the permitted use, you will need to obtain permission directly from the copyright holder.

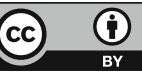

